\title{
ET FYSISK OBJEKT FRA KARDINAL NICOLAUS BREAKESPEARS LEGAT TIL NORDEN 1152-54
}

\author{
ERNST HÅKON JAHR
}

\begin{abstract}
A physical object from Cardinal Nicolaus Breakspear's legation to Scandinavia, 1152-54 This article gives an account of the background and discovery of the only remaining physical object from Cardinal Nicolaus Breakspear's legation to Scandinavia 1152-54 on behalf of Pope Eugenius III. The Pope had invested in Cardinal Breakspear the authority to negotiate and make decisions on the organisation of the church in the three Scandinavian kingdoms: Denmark, Norway and Sweden. Until then, the church in the whole of Scandinavia was under the archbishop of Lund. Lund at that time was part of Denmark, not of Sweden, as it is today. During his time in Norway, Cardinal Breakspear (c. 1100-1159) reorganised the Norwegian church under its own archbishop in Nidaros (Trondheim), and established a new Norwegian diocese in Hamar. The Pope's plan was in addition to establish another archbishopry in Sweden, but that could not yet be achieved due to internal Swedish disagreements. The Sweden church, therefore, remained under the archbishop of Lund. When Cardinal Breakspear left Scandinavia from the town of Lomma close to Lund, he somehow must have dropped a lead seal which was attached to a letter from the Pope. This seal was then accidentally refound in the middle of the 1980s when Mr. Per Olsson dug in his garden in Lomma. He thought he had found an old coin and kept it in a drawer in his house. Per Olsson's son, Magnus Linnarsson, later found out that the seal was from Pope Eugenius III. It is highly probable that this seal today is the only remaining physical artifact of Cardinal Breakspear's legation to Scandinavia 1152-54. Cardinal Breakspear soon after his return to Rome became the new Pope under the name (H)Adrian IV. Until Pope John Paul II visited Norway in 1989, Nikolaus Breakspear is the only Pope ever to have set foot in Norway, and that happened before he was elected Pope.

The seal is since 2011 included in the collections of Lund's Historical Museum.
\end{abstract}

Da kandinalbiskop Nicolaus Breakspear av Albano på forvinteren 1154 gikk om bord i et skip i Lomma, havnebyen til Lund, den gang en del av Danmark, kan han ha vært litt ergerlig og sur på seg sjøl. Han hadde mista noe viktig da han noe tidlig- 
ere hadde kommet til Lomma for å besøke erkebiskop Eskil i Lund. Han visste ikke nøyaktig hvordan det var gått til, men han kunne ikke la være å tenke på det, der han steg om bord i skipet som skulle føre han i retning Roma.

Han hadde nettopp avslutta et stort oppdrag fra pave Eugenius III. Breakespear, som var født i England omkring år 1100, var pavelig legat, dvs. utsending, utstyrt av paven sjøl med myndighet til å forhandle og ta avgjørelser om hele Nordens kirkeordning slik den skulle være fra da av og inn i framtida. Breakspear var legatus a latere, som betydde at han hadde den høyeste myndighet som en pavelig legat kunne ha. Som legatus a latere kunne han agere som pavens stedfortreder på nesten alle områder (Nilsson, 2017: 18).

Paven hadde nok valgt Breakspear til denne viktige oppgava nettopp fordi han var engelskmann. I den første kristninga av Norden, men særlig av Norge, hadde misjonærer fra de britiske øyene spilt ei svært viktig rolle, og Breakspear, som da var i begynnelsen av 50 -åra, hadde fullført oppdraget på beste måte.

I Nidaros, nå Trondheim, hadde Breakspear innsatt den tidligere stavangerbispen Jon Birgersson til første erkebiskop i den nyoppretta norske kirkeprovinsen. I tillegg oppretta han et nytt Hamar bispedømme, som blei skilt ut fra Oslo. Han besøkte også Hamar før han forlot landet, og tradisjonen sier at han stod bak opprettelsen av de første katerdralskolene i landet.

Nicolaus Breakspear gjorde et veldig inntrykk på nordmennene det året han var i landet. Etterpå blei han omtalt som Nikolaus den Gode, og slik er han omtalt av Snorre Sturlason i Sagaen om Haraldssønnene. Breakpear måtte politisk forholde seg til hele tre samtidige og konkurrerende konger i Norge. Det var de tre sønnene til kong Harald Gille: Inge Krokrygg, Øystein Haraldsson og Sigurd Munn. Han hadde mest sans for den gode Inge, mens Sigurd var for vill i levemåte etter kandinalens smak. Likevel klarte han som en dyktig politiker å navigere mellom de tre og bringe alle avtaler og ordninger i havn (Johnsen, 1945; Helle, 1996).

Men svenskene var det verre med. Én del av oppdraget hans i Norden hadde hadde Breakspear derfor ikke kunnet fullføres denne gangen. Sverige, motsatt Norge, hadde vist seg å ikke være klart til å bli egen kirkeprovins. De kunne ikke en gang bli enige om hvor erkebispesetet skulle være, da de hadde møte med Breakspear i bispesetet Linköping, antakelig på sommeren eller høsten 1153 (Nilsson, 2017: 20). Mens noen holdt på Uppsala, ønska andre at erkebispesetet skulle plasseres andre steder. Det er Saxo Grammaticus som melder dette i danmarkshistoria si fra rett etter 1200 (s.st.). Breakspear måtte konkludere at svenskene ikke var klare ennå til å få sin egen kirkeprovins.

Pave Eugenius III hadde sendt med Breakspear to pallier til Norden. Et pallium er et slags ullskjerf eller stola. Det bæres om halsen, er hvitt og med innsydde svarte kors. Bare paven sjøl og erkebiskoper kunne bære et pallium. Når derfor kandinal Breakspear fikk med seg to slike pallier på sin legasjon til Norden, var meninga opplagt at det skulle etableres to nye kirkeprovinser med egne erkebiskoper, utskilt 
fra Lund erkebispedømme i Danmark. Men kandinal Breakspear måtte overlate ett pallium til erkebiskop Eskil i Lund, i påvente av at Sverige kunne etableres som eget erkebispedømme.

Det er ikke sikkert at erkebiskop Eskil, som var jamgammel med kandinalen, og som Breakspear hadde besøkt rett før han nå drog fra Lund og Lomma på veg til Roma, var direkte lei seg for at Breakspears oppdrag hadde mislyktes i Sverige. Lund lå så sentralt plassert $\mathrm{i}$ Norden som tenkelig var. Men Norden var et veldig stort område å dekke for bare én erkebiskop, og nå var det av ulike grunner også politisk hensiktsmessig for paven å dele Norden opp i tre kirkeprovinser (Rennie, 2013). At Sverige ikke blei skilt ut denne gangen, kom nok som en skuffelse i Roma, men kanskje som en lettelse i Lund. Tolv år seinere, i 1164, blei imidlertid også Sverige skilt ut fra Lund, og da med Uppsala som erkebispesete (Inger, 1961).

Så dette lå bak han av utført gjerning da Nikolaus Breakspear la ut fra Lomma med endelig kurs for Roma. Der var den paven død som sendte han ut, og en ny, Anastasius IV, hadde tatt over. Det var han som ved Breakspears gjenkomst til Roma sendte bekreftelsesbrev til erkebiskop Jon i Nidaros, med stadfesting av alle de avtaler og ordninger som Breakspear hadde kommet fram til i det året han var i Norge.

Men det var altså noe annet som kan ha ergra Nicolaus Breakspear veldig da han gikk om bord i skipet i Lomma, i tillegg til at svenskene hadde vist seg mer kirkelig umodne enn paven og han i utgangspunktet hadde trodd. Han hadde altså mista noe veldig viktig. På en eller annen måte hadde et pavelig segl, en bulle, blitt borte for han. Kanskje var det det seglet som hang ved brevet fra pave Eugenius 3 til erkebiskop Eskil i Lund, der paven utnevnte Eskil til Nordens „Vicarius”. Det var nesten som en liten pave. Pavens refererte nemlig til seg sjøl som „Vicarius Christi”, stedforstreder for Kristus. Dette var således ingen liten tittel å få for erkebiskop Eskil som kompensasjon for at han mista Norge fra området sitt, og etter planen skulle ha mista Sverige også.

Kanskje det altså var fra dette brevet at seglet, bullen, var blitt borte. Seglet, som var av bly, hadde vært sydd inn i brevet med en tråd som gikk tvers gjennom seglet. En slik tråd var enten av silke eller av hamp, litt avhengig av innholdet i brevet. Her hadde det nok vært hamp. Dermed burde det ha vært solid festa til brevet. Det var et slikt segl som garanterte for at brevet var ekte, og at paven virkelig var avsender.

Det pavelige blyseglet hadde ca. 1100 fått et fast utseende: På den ene sida vistes hodene til apostlene Paulus og Peter med et kors imellom, og med bokstavene SPA og SPE over (for Sanctus PAulus og Sanctus PEter). Latin 'sanctus' betyr 'hellig'. Paulus var avbilda med langt skjegg, mens Peter hadde krøllete hår og kort skjegg. På den andre sida stod pavens navn. Slik var paveseglet til helt ut på 1400-tallet. Opprinnelig kaltes paveseglet for „bulle” (latin 'bulla'), og det ordet gikk deretter over til å betegne sjølve det pavelige dokumentet. Uten et slikt segl kunne en adressat den gangen, i mellomalderen, begynne å tvile på autentisiteten, ektheten, av brevet. Å miste et segl fra et viktig brev var derfor svært alvorlig, og det 
må ha irritert Breakspear veldig at han hadde klart å gjøre det. At det var blitt borte i Lomma, det var han ganske sikker på.

Brevet, uten segl, blei nok likevel overrakt erkebiskop Eskil, og han blei muligens så fornøyd med å bli utnevnt til „vicarius”, at han ikke brydde seg om det manglende seglet. Dessuten var det garanti godt nok at det var kandinal Breakspear sjøl som overleverte det. Det var ingen grunn til å tvile på at brevet var ekte, og at det virkelig var fra pave Eugenius III.

Kardinal Nicolaus Breakspear rista nok raskt av seg ergrelsen han måtte ha hatt på grunn av det tapte paveseglet da skipet stod ut fra Lomma, og han hadde begynt den lange reisa tilbake til Roma. Ikke lenge etter at han var kommet tilbake, døde den nye paven, Anastasius IV, etter bare ett år på pavestolen. Da blei kardinal Nicolaus Breakspear valgt til ny pave, 4. desember 1154, og han tok navnet Adrian IV (ofte omtalt som Hadrian IV). Han døde 1. september 1159. Adrian IV er den eneste paven i historia som er født i England.

Før pave Johannes Paul II besøkte Norge i 1989, var Nicolaus Breakspear den første og eneste paven som hadde vært i Norge, og hans besøk 1152-53 var altså noe før han blei regjerende pave.

Midt på 1980-tallet, bare noen år før pave Johannes Paul II besøker Norden, graver en mann i hagen sin i Lomma. Per Olsson, som mannen heter, skal anlegge en blomsterrabatt. I motsetning til i høymiddelalderen, da Lomma var en strategisk viktig by og havn i Skåne - da en del av Danmark -, er Lomma nå nærmest en liten landsby. Der han planlegger blomsterrabatten, finner Per Olsson noe i jorda. Han mener det må være en tung mynt. Den ligger tungt i handa, og når han måler den, er den $32 \mathrm{~mm}$ i diameter. Han undrer seg litt over at det ikke står noen angivelse av verdi på mynten. Han gjør den rein, og legger den i en skuff.

„Mynten” blir liggende i skuffen til 2008, da Per Olssons sønn, historikeren Magnus Linnarsson, tar den med til det Kongelige myntkabinettet i Stockholm. Der ser de straks at det ikke dreier seg om en mynt, men et gammelt pavelig segl. Det var en bulle fra pave Eugenius III, som var regjerende pave 1145-1153.

Det Per Olsson fant i hagen sin, var var etter all sannsynlighet det paveseglet Nicolaus Braekspear mista i Lomma i 1153 eller 1154. Iallfall mista han det før han forlot Norden etter et opphold på nesten to år, og etter å ha etablert en kirkeprovins i Norge med ordninger som i prinsippet varte uendra i nesten 400 år, helt til reformasjonen i 1536. På baksida av seglet leser vi pavens navn skrevet over tre linjer: EVGENIVS PP III. „PP” står for latin 'Papa' = pave. På forsida finner vi portretta av Paulus og Peter. Dette paveseglet er ikke bare et bevis på forbindelsen mellom pavestolen og Norden i 1152/53, men det representerer også det eneste handfaste og fysiske objektet vi har i Norden i dag fra Nicolaus Breakspears legasjon til Norge og Norden 1152-54. (I 2017 blei det funnet et nytt pavesegl fra middelalderen i Norden, denne gangen i Oslo. Det var fra Innocens IV, som var pave 1243-1254. Seglet har rimeligvis sittet på et pavebrev til biskopen i Oslo.) 
Den 26. mai 2011 møttes forfatteren av denne artikkelen og Magnus Linnarsson i Lund. Linnarssen hadde da med seg det pavelige seglet som far hans hadde funnet i Lomma midt på 1980-tallet. Etterpå gikk vi sammen til Lunds Universitets Historiska Museum, der Magnus Linnarsson overleverte seglet til museet. Ulla von Wowern tok imot og registrerte det på vegne av museet.

Det er et viktig stykke norgeshistorie som dermed nå ligger trygt forvart i samlingene til museet $i$ Lund.

\section{Referanser}

Helle, Knut. 1996. Norge blir en stat: 1130-1319., Bd. 3 av Handbok i Norges historie, 4. opplag. Oslo: Universitetsforlaget.

Inger, Göran. 1961. Das kirchliche Visitationsinstitut im mittelalterlichen Schweden (= Bibliotheca Theologiae Practicae, XI). Lund: Gleerup.

Johnsen, A.O. 1945. Studier vedrørende kardinal Nicolaus Brekespears legasjon til Norden. Oslo: Fabritius.

Nilsson, Bertil. 2017. „Ett antal misslyckanden? Påvliga legater til Sverige under medeltiden.” Arsberättelse. Bulletin de la Société Royale des Lettres de Lund 2016-2017. Lund: Kungl. humanistiska vetenskapssamfundet i Lund. 17-26.

Rennie, Kriston R. 2013. The foundations of medieval papal legation. Basingstoke: Palgrave Macmillan. 